C 1986 ISIJ

チタン合金の電子構造と相安定性

論 文

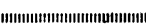

森永 正彦*·湯川 夏夫*2 $\cdot$ 足立 裕彦*3

\title{
Electronic Structure and Phase Stability of Titanium Alloys
}

\author{
Masahiko Morinaga, Natsuo Yukawa and Hirohiko Adachi
}

\begin{abstract}
Synopsis :
The alloying effect has been investigated on the electronic structure of both bcc $\mathrm{Ti}$ and hcp Ti by the DV-X $\alpha$ cluster method. The two alloying parameters which are the metal $\mathrm{d}$-orbital level (Md) and the bond order between atoms (Bo), were determined theoretically. The $\mathrm{Md}$ is related to the electronegativity and metallic radius of elements. The Bo is a measure of the strength of the covalent bond between titanium and alloying elements. Both the $\mathrm{Md}$ and the Bo change remarkably with alloying elements.

A new approach based on the electronic theory has been developed for understanding the phase stability of titanium alloys. With using Md and Bo parameters, titanium binary phase diagrams are interpreted consistently, and various commercial alloys are classified into the three groups of the $\alpha, \alpha+\beta$ and $\beta$ alloys. The $\beta$ transus and the Ms temperature for the martensitic transformation are predicted from alloy compositions. Furthermore, the activation energy for the impurity diffusion in bcc Ti is estimated in terms of the Bo.
\end{abstract}

\section{1. 緒}

軽く強く銷び難い性啠をもつチタン合金は，最近特に 注目を集めている材料である.チタン合金を理解し，新 合金を開発するためには，それに含まれている金属元素 の合金中に抖斿振舞いを知ることが必要である。これ まで純チタンの電子構造は，バンド理論により計算さ れ(1) 6)，また種々の実験により調べられている7) 11)。例 えば, 計算によつて求められたフェルミ面は, ド・ハー スーファン・アルフェン效果の奏験により確かめられて いる77。 また XPSやUPS の奏験結果もバンド計算の 結果と比較的艮い対応がある8 ${ }^{80)}$. しかしながら, チタ ン合金の電子構造を取り扱つたものはこれまでほとんど 無い.

そこで本研究では，低温相である最密六方格子 (hcp) の $\alpha-\mathrm{Ti}$ ，および高温相である体心立方格子 (bcc) の $\beta-\mathrm{Ti}$ の中の種々の命金元素の電子状態を, DiscreteVariational (DV) - X $\alpha$ クラスター法12) 14)を用いて計算 した．金属，合金の評価パラメーターとして，従来より 使われている金属半径，電気陰性度あるいは一原子当た りの平均価電子数 $(e / a)$ などに替わる各種金属元素の 合金効果を表わす基本的なパラメーターを求めた。 また それらを用いて，主としてチタン合金の相安定性を評価
した。

\section{2. 電 子 構 造}

\section{$2 \cdot 1 \mathrm{DV}-\mathrm{X}_{\alpha}$ クラスター法}

本法は，数個〜数十個からなる原子の集合体（クラス ター）模型を用いて行ら分子軌道計算法である ${ }^{12) 13)}$. 電 子の交換ポテンシャルとして, SLATER の提案した $X_{\alpha}$ ポテンシャル， $V_{X C}(r)$ を用いる。

$$
V_{X C}(r)=-3 \alpha\left[\frac{3}{8 \pi} \cdot \rho(r)\right]^{1 / 3} .
$$

ここで $\rho(r)$ は電子密度で, パラメーター $\alpha$ は本研究 では 0.7 を用いた. 永年方程式を解くとき, 空間にラン ダムに選んだサンプル点で, ハミルトニアンと重なり積 分の行列要素を求める. 分子（クラスター）の波動方程 式を構成原子の軌道関数の 1 次結合で表す ${ }^{14)}$. 本研究で は, 原子軌道関数として, $\mathrm{Ti} の 1 s \sim 4 p$, 合金元素Mの $1 s \sim \mathrm{n} p$ (ただし $M$ が $3 d$ 金属のときは $n=4 ， 4 d$ 金属の ときは $n=5,5 d$ 金属のときは $n=6)$ を使用し, セルフ コンシステントに分子（クラスター）の波動関数を求め た.

Fig. 1 飞本計算で用いたクラスター模型を示す．（a ） は, bcc の $\beta$ - $\mathrm{Ti}$ の計算に使つた $\left(M \mathrm{Ti}_{14}\right)$ クラスター で, (b)は, hcp の $\alpha$ - $\mathrm{Ti}$ の計算に使つた $\left(M \mathrm{Ti}_{18}\right)$ ク

炤和 60 年 4 月本会講演大会にて発表 炤和 60 年 7 月 2 日受付 (Received July 2, 1985)

* 豊橋技術科学大学 Ph. D. (Toyohashi University of Technology, 1-1 Hibarigaoka, Tempaku-cho Toyohashi 440)

*2 豊橋技術科学大学 工情 (Toyohashi University of Technology)

*3 兵庫教育大学 工博 (Hyogo University of Teacher Education) 
ラスターである・いずれのクラスター模型も，中心に在 る合金元素 $M$ と，それから第 1 および第 2 近接位置にあ る $\mathrm{Ti}$ 原子からなつている. 中心の合金元素 $M$ として は，周期表から重要と思われる $3 d ， 4 d$ および $5 d$ 金属 14 種と，非遷移金属 $\mathrm{Al}, \mathrm{Si}, \mathrm{Sn}$ を選び計算した．格 子定数は実験で求められている值, すなわち（a）の $\beta$ $\mathrm{Ti}$ では $a=0.3320 \mathrm{~nm},(\mathrm{~b})$ の $\alpha-\mathrm{Ti}$ では, $a=0.2950$ $\mathrm{nm}, c=0.4683 \mathrm{~nm}$ を用いた ${ }^{15)}$.

\section{2 エネルギーレベル權造}

Fig. 2 に $\beta$-Ti の電子のエネルギーレベル構造を示 す.これは $M$ が $3 d$ 金属のときの計算結果である.図の

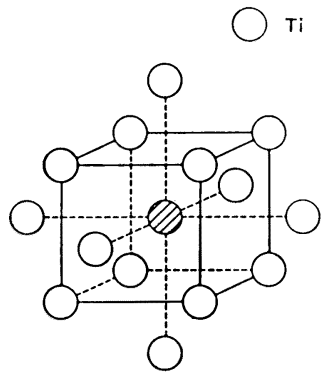

(a) b.c.c.Ti

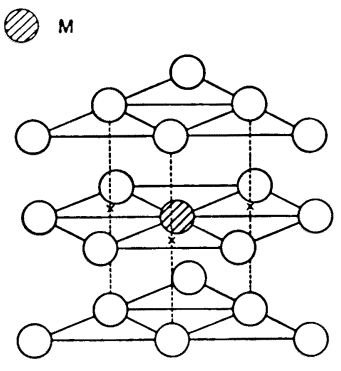

(b) h.c.p.Ti
Fig. 1. Cluster models employed in the calculation: (a) $\left(\mathrm{MT}_{14}\right)$ cluster for bcc $\mathrm{Ti}$ and (b) $\left(\mathrm{MTi}_{18}\right)$ cluster for hcp Ti.

左端は，Mが $\mathrm{Ti}$ のとき，すなわち $\mathrm{Ti}_{15}$ クラスターの レベル構造である. $18 t_{1 u}$ から $5 e_{u}$ のレベルは主に Ti$3 d$ 成分からなり， $3 d$ バンドを形成する．フェルミ準位 の位置は矢印で示すように，このバンドの中にある. $15 a_{1 g}$ 以下あるいは $13 e_{g}$ 以上のレベルには, $3 d$ 成分の ほか, $\mathrm{Ti}-4 s, 4 p$ 成分もかなり含まれている. エネルギ 一が約 $2.5 \mathrm{eV}$ の近傍に $16 t_{2 g}$ と $13 e_{g}$ の二つのレベル があるが，これらはクラスターの中心の $\mathrm{Ti}(=M)$ のd 軌道成分を含むレベルである. $16 t_{2 g}$ と $13 e_{g}$ には， $d$ 成分がそれぞれ $40 \% ， 59 \%$ 含まれている. 中心の原子 を $\mathrm{Ti}$ からMV置換すると，これら $M-d$ 成分に関係の あるレベルの位置は, 図に示すように周期表の順に単調 に下がる. またその $d$ 成分の割合も变化している.この ようなレベル（以下 $M_{d}$ レベルと略称）は， $\mathrm{Ni}$ 合金(4) や Fe 合金备)の電子構造の計算でも現れる.

純チタンの $\mathrm{Ti}_{15}$ クラスターのレベル構造から計算し た電子の状態密度は, SNOW と WABER のバンド計算の 結果 ${ }^{17)}$ と似ている。ただし本計算で求まつた $d$ バンドの 幅は約 $5 \mathrm{eV}$ であり，彼らの $8 \sim 9 \mathrm{eV}$ よりかなり小さ く, むしろ PETTIFOR の報告 ${ }^{18)}$ の約 $6 \mathrm{eV}$ に近い. Fig. 2 と同様なレベル構造が $M$ が $4 d, 5 d$ 金属の場合にも求 められた。

hcp の $\alpha-\mathrm{Ti}$ でもレベル構造が計算された. この場 合, クラスターの対称性が bcc のそれに比べ低いため,

\section{$3 d$}

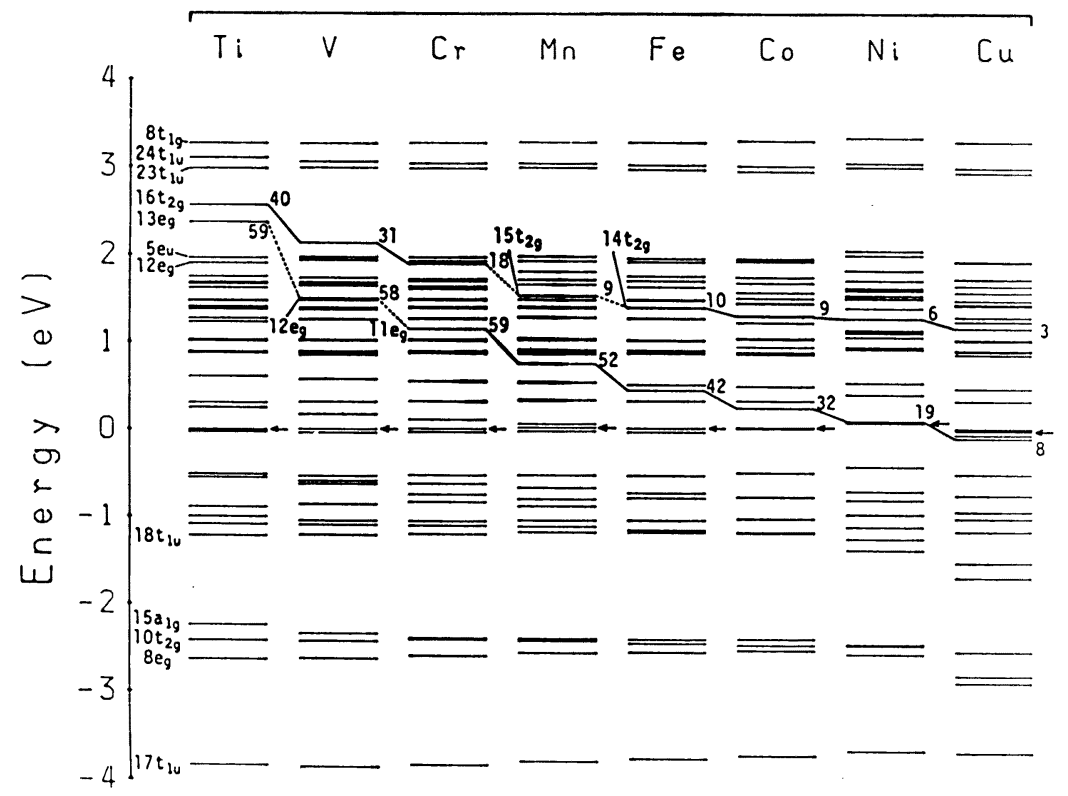

Fig. 2. Energy level structure of the bcc Ti, containing $3 d$ transition metals. The Fermi level is indicated by an arrow $(\leftarrow)$. 


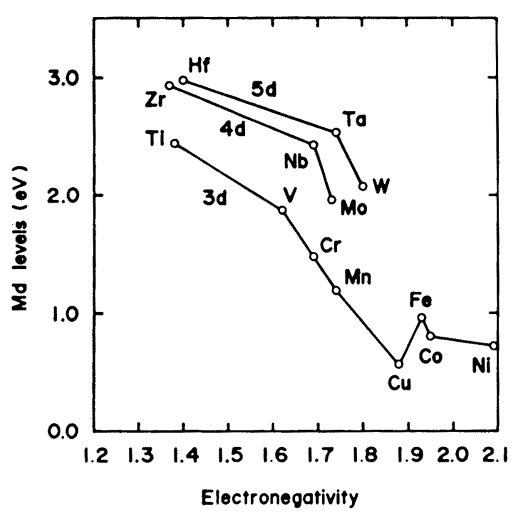

Fig. 3. Correlation of the Md level with the electronegativity.

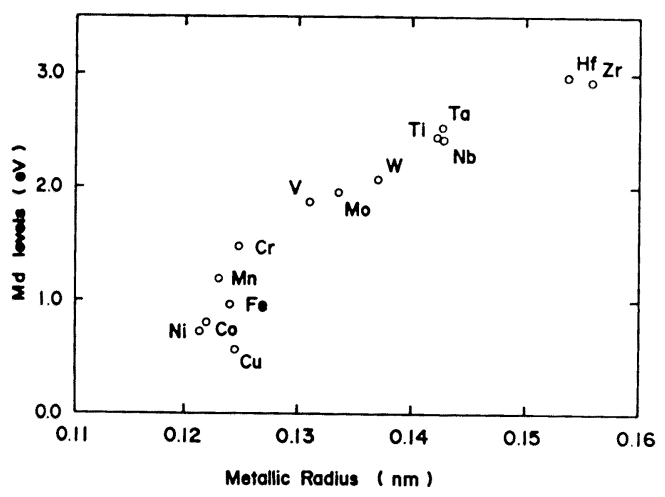

Fig. 4. Correlation of the Md level with the metallic radius.

電子のエネルギーレベルの縮退がとけ，レベル構造はや や複雑である. その $d$ バンドの幅は約 $6 \mathrm{eV}$ である.

\section{$2.3 M_{d}$ レベルと電気陰性度と金属半径}

Fig. 3 に示すように, $M_{d}$ レベルは $M$ 原子の電気陰 性度と相関がある.ここで用いた $M_{d}$ は, Fig. 2 で示 した $e_{g}$ と $t_{2 g}$ レベルの平均值である. 電気㓌性度の值 としては, WATSON と BENNETT が報告しているdバン ドの性質を用いて決めた值を使つた ${ }^{19)}$ 。電気陰性度が小 さい原子ほど，電子を周りの原子に与える傾向が大き い.また原子の $M_{d}$ レベルが高いと，低いレベルをも つ原子へ電荷の移行が起こる. 従つて Fig. 3 にみられ るように，電気陰性度が小さい原子ほど，その $M_{d}$ レ ベルの位置も高くなる.

$M_{d}$ レベルはまた金属半径とも関係があるＦig. 4 は縦軸に $M_{d}$, 横軸に TEATUM ら ${ }^{20)}$ の報告による配位 数 $\mathbf{C N}=8$ の場合の金属半径をとつている. 金属半径が 大きくなるほど, $d$ 軌道の平均半径も大きくなり，その 結果 $d$ 電子が中心の原子核から受ける束縛力も小さく

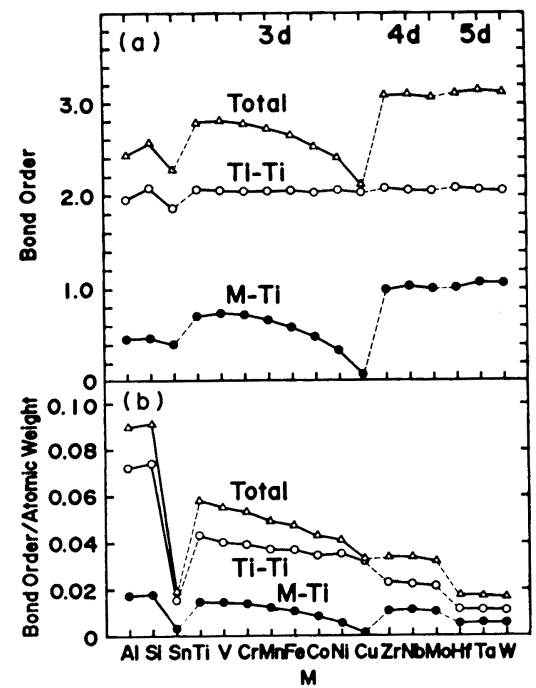

Fig. 5. Change of (a) the bond order and ( $b$ ) the ratio of bond order to the atomic weight with alloying elements $\mathrm{M}$ in bcc $\mathrm{Ti}$.

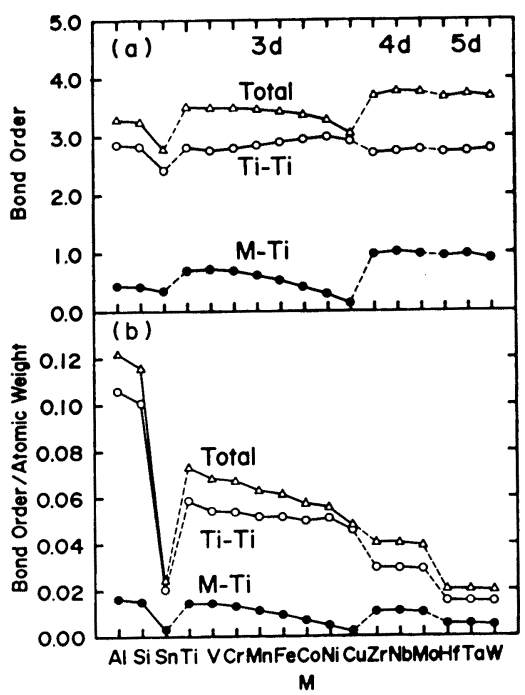

Fig. 6. Change of (a) the bond order and (b) the ratio of bond order to the atomic weight with alloying elements $\mathrm{M}$ in hcp $\mathrm{Ti}$.

なる.このため $M_{d}$ レベルも高くなる.このような関 係は, $\mathrm{Ni}$ 合金14)や $\mathrm{Fe}$ 合金 ${ }^{16)}$ でも見出されている.

\section{4 結合次数}

一般に, チタンなど不対 $d$ 電子をもつ遷移金属では, $d$ 電子間の共有結合力がたいせつで, これが金属の凝集 エネルギーの大きな割合を占めている21). その大ささを 示すパラメーターとして結合次数が計算により求まる. 結合次数は原子間の電子の重なり積分に比例する. 結合 
次数の合金元素 $M$ に対する変化を, Fig. 5 (a) $\beta-\mathrm{Ti}$ と Fig. 6 (a) $\alpha$-Ti に示す. これらの図中の $M$-Ti は, $M-d$ と $\mathrm{Ti}-3 d$ の間の結合次数であり, $\mathrm{Ti}-\mathrm{Ti}$ は $M$ 原 子の周囲にある $\mathrm{Ti}$ 原子の問の結合次数である.すなわ ち Ti-3d ぞうしの結合の程度を示す. 全体 (Total) は, これらの和である.この值が大きい合金元素 $M$ の添加 は, 母金属の $\mathrm{Ti}$ と電子的結合を強めるため, 材料の強 化に有効である2223)。例えば $3 d$ 金属では， $\mathrm{V}, \mathrm{Cr}$ が $\mathrm{Ti}$ と同程度の結合次数をもつ．また $4 d ， 5 d$ 金属の結 合次数は $3 d$ 金属のもの上り大きい. 非遷移金属の $\mathrm{Al}$, $\mathrm{Si}, \mathrm{Sn}$ の結合次数もそれほど低くない。これらのこと は, $\alpha-\mathrm{Ti} と \beta-\mathrm{Ti}$ 両方についてい充, あり結晶構造 に依存しない。

軽くて強いことが特長である $\mathrm{Ti}$ 合金では，比強度が 問題となる。これを考虑するため，(結合次数)/(原子 量)を計算した. Fig. 5 (b) は $\beta$-Ti，Fig. 6 (b) は $\alpha-\mathrm{Ti}$ の結果である.この此は，例觉ば $3 d$ 金属におい ては，周期表での位置が $\mathrm{Ti}$ から遠ざかるにつれて単調 飞減少している。また $5 d$ 金属ではこの值が著しく小さ い. $5 d$ 金属の添加は高温強度に対して有効かもしれな いが，主要合金元素として積極的に添加する必要はない よらに考兄れる. Fig. 5，Fig. 6 を総合して考える と，強力なチタン合金を作るときの合金元素として，3d 金属では $\mathrm{V}, \mathrm{Cr}, 4 d$ 金属では $\mathrm{Zr}, \mathrm{Nb}, \mathrm{Mo}$ ，そして非 遷移金属では $\mathrm{Al}, \mathrm{Si}, \mathrm{Sn}$ が考光られる。代表的なチ夕 ン合金である Ti-6Al-4V では, Fig. 5 (b), Fig. 6 (b) より明らかのように，たいへん優れた合金元素の選 択が行われている．多くの先用チタン合金は，上䛉の結 合次数から考えた合金元素を主要合金元素として含んで いる (Fig. 8 の実用合金リスト参照).

\section{5 合金の平均 $\overline{\boldsymbol{M}}_{d}$ と 平均 $\overline{\boldsymbol{B}}_{\mathbf{0}}$}

合金においては， $M_{d}$ と結合次数 ( $B_{0}$ と略称) の平 均值をそれぞれ次のように組成平均で定義する．

$$
\begin{aligned}
& \bar{M}_{d}=\Sigma X_{i} \cdot\left(M_{d}\right)_{i} \\
& \bar{B}_{0}=\Sigma X_{i} \cdot\left(B_{0}\right)_{i}
\end{aligned}
$$

ここで $\left(M_{d}\right)_{i},\left(B_{0}\right)_{i}$ 快それぞれ $i$ 原子の $M_{d}, B_{0}$ 值 であり， $X_{i}$ は $i$ の原子分率である. $M_{d}$ と $B_{0}$ の值は それほど結晶構造に敏感ではないので14)16), 以下の解析 では， $\alpha$ 相合金にも $\beta$ 相で求めた值を近似的に使つた。

\section{3. チタン合金の特性評価}

\subsection{2 元系合金状態図の整理}

Fig. 7 は, Ti-M 2 元系合金の平衡状態図と $B_{0}$ と $M_{d}$ の対応を示したものである. $M$ が遷移金属のとき は，状態図は $(\mathrm{A}) \sim(\mathrm{C})$ の 3 種に大別される ${ }^{15)}$. (A)は

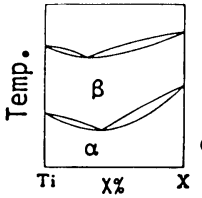

(A)

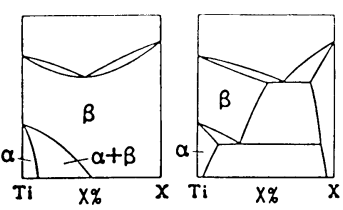

(B)

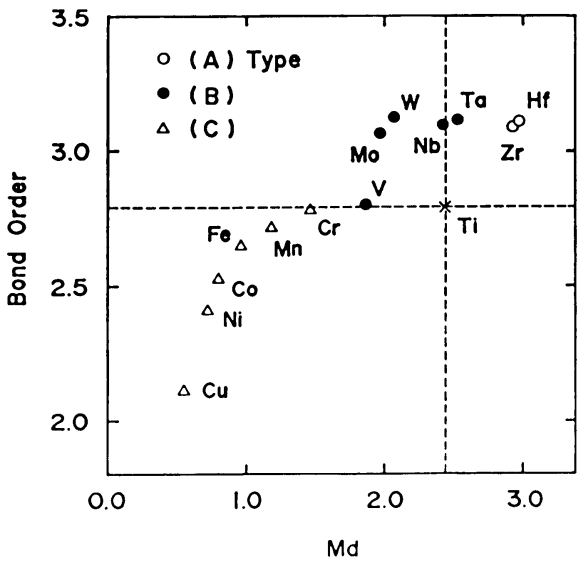

Fig. 7. Representation of titanium binary phase diagrams in the $B_{0}-M_{d}$ map.

$\alpha-\beta$ 全率固溶休型，(B)は $\beta$ 全率洞溶体型，および $(\mathrm{C})$ は $\beta$ 共析型である. $B_{0}-M_{d}$ 線四の中で, これら 3 種の タイプは，それぞれある领域にかたまつて存在する。 $\mathrm{Ti}$ より $\beta$ 相中の結合次数が大きい合金元素 $M$ は, (A) または $(\mathrm{B})$ タイプのように，高温で $\beta$ 全率固溶体とな る. 反対纪結命次数が小さいと, $(\mathrm{C})$ タイプのように $\beta$ 領域が制限される。 $\beta$ 領域の広さは, $\mathrm{Cr}>\mathrm{Mn}>\mathrm{Fe}>$ $\mathrm{Co}>\mathrm{Ni}>\mathrm{Cu}$ の順になつている。 また横軸の $M_{d}$ でみ れば $\mathrm{Ti}$ と $M_{d}$ が近い合金元素 $M$ が $(\mathrm{A})$ または $(\mathrm{B})$ タイ プの状態図を示す．Wは今まで $(\mathrm{C})$ タイプに入れられて いたが，最近の研究によれば24)，Fig. 7 で示すように $(\mathrm{B})$ タイプであり， $B_{0}-M_{d}$ 線図の予想と合つている.

\section{2 実用チタン合金の分類}

垁用チタン合金は，通常 $\alpha$ 型， $\alpha+\beta$ 型， $\beta$ 型に大 別される15)。ただし， Near $\alpha$, Near $\beta$ はそれぞれ $\alpha$ 型, $\beta$ 型に含めて考光ることとする.

在来の主要チタン合金約 40 種について，その組成よ り式(2)，（3)を用いて $\bar{M}_{d}, \bar{B}_{0}$ を求め, Fig. 8 の $\bar{B}_{0}-M_{d}$ 線図の中にプロットした。 図より明らかのよう に, $B_{0}-\bar{M}_{d}$ 線図上で，これらの合金はそのタイプによ $り$ 明瞭に分離している。すなわち $\beta$ 相合金は, $\bar{B}_{0}$ の高 いところに彸がり，その下に $\alpha+\beta$ 相合金があり， $\alpha$ 相合金は， $B_{0}$ が低くて, $M_{d}$ が比較的大きい領域にか たまつて存在している. $M_{d}=2.35, B_{0}=2.78$ 近傍の $\beta$ 


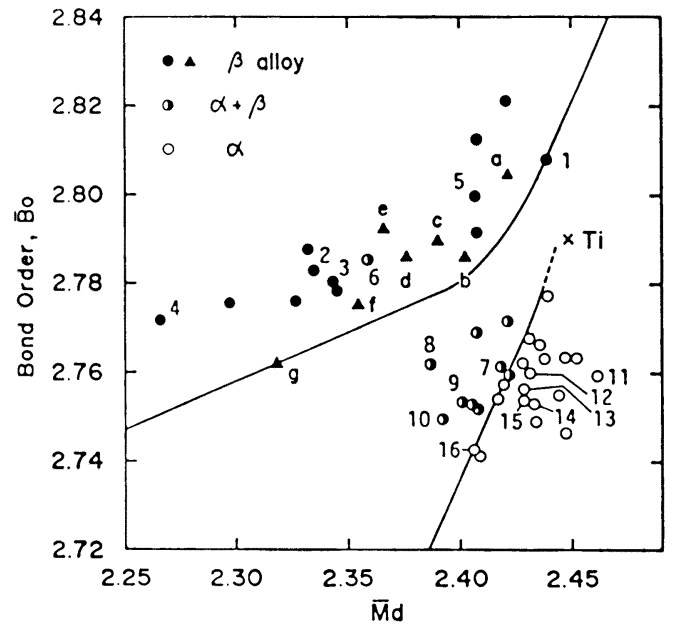

Ti Alloys

$1 \mathrm{Ti}-4.5 \mathrm{Sn}-11.5 \mathrm{Mo}-6 \mathrm{Zr}$ (Beta III)

2 Ti-3AI-8V-4Zr-4Mo-6Cr (Beta C)

$3 \mathrm{Ti}-3 \mathrm{Al}-8 \mathrm{~V}-8 \mathrm{Mo}-2 \mathrm{Fe}$ (8-8-2-3)

$4 \mathrm{Ti}-3 \mathrm{Al}-13 \mathrm{~V}-11 \mathrm{Cr}(13-11-3)$

$5 \mathrm{Ti}-15 \mathrm{Mo}-5 \mathrm{Zr}-3 \mathrm{Al}$

$6 \mathrm{Ti}-8 \mathrm{Mn}(8 \mathrm{Mn})$

7 Ti-6Al-6Mo-2Sn-4Zr (6-2-4-6)

$8 \mathrm{Ti}-5 \mathrm{Al}-2 \mathrm{Sn}-2 \mathrm{Zr}-4 \mathrm{Mo}-4 \mathrm{Cr}(\mathrm{Ti}-17)$

9 Ti-6Al-4V (6-4)

$10 T i-6 A l-6 V-2 S n(6-6-2)$

$11 \mathrm{Ti}-2.25 \mathrm{AI}-11 \mathrm{Sn}-5 \mathrm{Zr}-1 \mathrm{Mo}-0.2 \mathrm{Si}$ (IMI-679)

$12 \mathrm{Ti}-6 \mathrm{Al}-0.5 \mathrm{Mo}-5 \mathrm{Zr}-0.2 \mathrm{Si}$ (IMI-685)

$13 \mathrm{Ti}-6 \mathrm{Al}-2 \mathrm{Mo}-2 \mathrm{Sn}-4 \mathrm{Zr}(6-2-4-2)$

14 Ti-5AI-6Sn-2Zr-1Mo-0.2Si (IMI-829)

15 Ti-5Al-2.5Sn (A-110)

16 Ti-8A1-1V-1Mo (8-1-1)

$\mathrm{Ti}-\mathrm{M}(\mathrm{a}) \mathrm{M}=\mathrm{Mo}(\mathrm{b}) \mathrm{Fe}(\mathrm{c}) \mathrm{Cr}(\mathrm{d}) \mathrm{Mn}(\mathrm{e}) \mathrm{V}$

(f) $\mathrm{Co}(g) \mathrm{Ni}$

Fig. 8. Grouping of commercial titanium alloys into the three types of the $\alpha, \alpha+\beta$ and $\beta$ alloys in the $\bar{B}_{0}-\bar{M}_{d}$ map.

領域にある No. 6 の Ti-8Mn は $\beta$ 相合金であるが, 機械的性質の改善のため $\alpha+\beta$ 温度領域で熱処理をされ る25).このため分類上 $\alpha+\beta$ 相会金に入れられているも ので，本質的な食い違いがあるわけではない，最強のチ タン合金といわれる Ti-6Al-6Mo-2Sn-4Zr (6-2-4-6) は, No. 7 で $\alpha$ 領域と $\alpha+\beta$ 領域の境界近くにある. 一方, Ti-6Al-4V は, No. 9 で $\alpha+\beta$ 領域の中ほどに あり, 少しの組成変動に対しても性質があまり敏感に変 化しないことが尔される，この想さ味で，6-2-4-6に比 べ製造しやすい合金といえるかもしれない26).

合金組成が与えられれば，その $B_{0} ， M_{d}$ を計算し， Fig. 8 と比較すれば，それがどのタイブの合金である か分かる. Fig. 9 に，チタンに他の合金元素 $M$ を入れ たとき，合金が $B_{0}-M$ 線図上，どの方向に動くかを示 す.例えば，Mo，W などを入れると， 線図上， Ti の 位置から左上方へ動き， Fig. 8 の $\beta$ 領域に入る.一 方, $\mathrm{Al}, \mathrm{Sn}$ などの添加は, 線困上, 右下方に動くため, Fig. 8 の $\alpha$ 領域に入つていく. このよらに, Mo, W などは $\beta$ 相安定化元素であり, $\mathrm{Al}, \mathrm{Sn}$ は $\alpha$ 相安定化 元素となり, 従来の実験と一致している15).

\section{$3.3 \beta$ トランザスの予測}

状態図において， $\beta$ 単相域と $(\alpha+\beta) 2$ 相混合域の境 界を $\beta$ トランザスといい，それ以上の温度では $\beta$ 単 相である.

Fig. 10 は, 各種合金 $(a \sim i)$ の 3 元素状態図 ${ }^{27}$ の $\beta$ トランザスを $B_{0}-M_{d}$ 線困上に整理したものである.

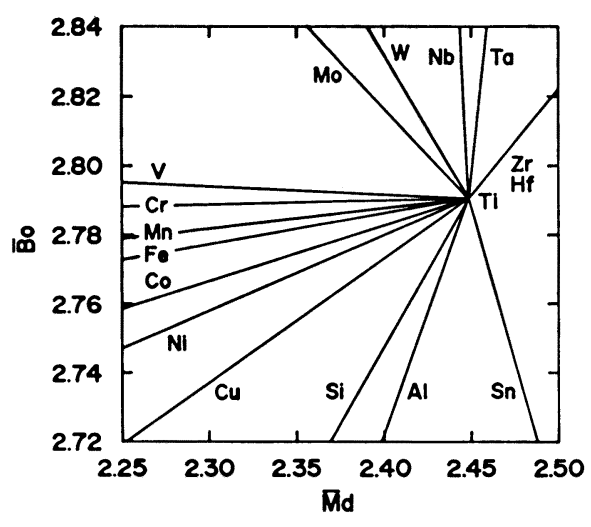

Fig. 9. $\bar{B}_{0}-\bar{M}_{d}$ lines drawn for various Ti-M binary alloys.

例えば， $B_{0}$ が低いところにある実線の $\mathrm{a}$ は，1 $1273 \mathrm{~K} の$ Ti-Al-Mn の等温状態図から， $\beta / \alpha+\beta$ 相境界線の組 成を読又取り, その平均 $\bar{B}_{0}, \bar{M}_{d}$ を計算して $\bar{B}_{0}-\bar{M}_{d}$ 線図上に描いたものである. 実線の b は Ti-Al-Mo, d は $\mathrm{Ti}-\mathrm{Al}-\mathrm{V}, i$ は $\mathrm{Ti}-\mathrm{Al}-\mathrm{Cr}$ である.これらの曲線は， 合金系にあまり関係なく，ほ區じ $\bar{B}_{0}-\bar{M}_{d}$ 線図上の位 置を占めている. $\beta$ トランザスが， $1173 \mathrm{~K}, 1073 \mathrm{~K}$, $973 \mathrm{~K}$ と下がるにつれて, その位置は, 高 $\bar{B}_{0}$ 側へ移動 している.

それぞれの温度における曲線群を一つの直線で近似す れば, Fig. 11 に示すように, 等間隔の 4 本の直線が引 ける、比較のため, 図中に実用合金の $\beta$ トランザスが 


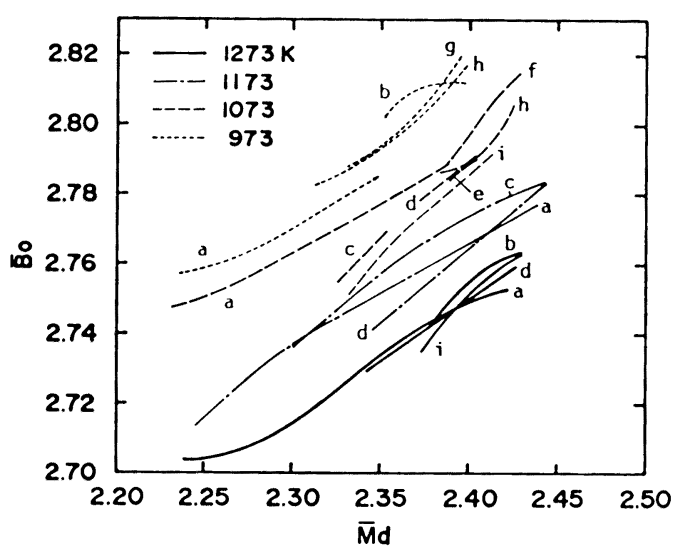

Ternary systems : a $\mathrm{Ti}-\mathrm{Al}-\mathrm{Mn}$, b $\mathrm{Ti}-\mathrm{Al}-\mathrm{Mo}$, c $\mathrm{Ti}-\mathrm{Al}-\mathrm{Ni}$, d Ti-Al-V, e Ti-Cr-Fe, f Ti-Cr-W, g Ti-Mo-Cr, h Ti-Mo-Mn, i Ti-Al-Cr

Fig. 10. $\beta$ transus curves in the $\bar{B}_{0}-\bar{M}_{d}$ map. The $\beta$ transus from $973 \mathrm{~K}$ to $1273 \mathrm{~K}$ is taken from ternary alloys, $(a-i)$.

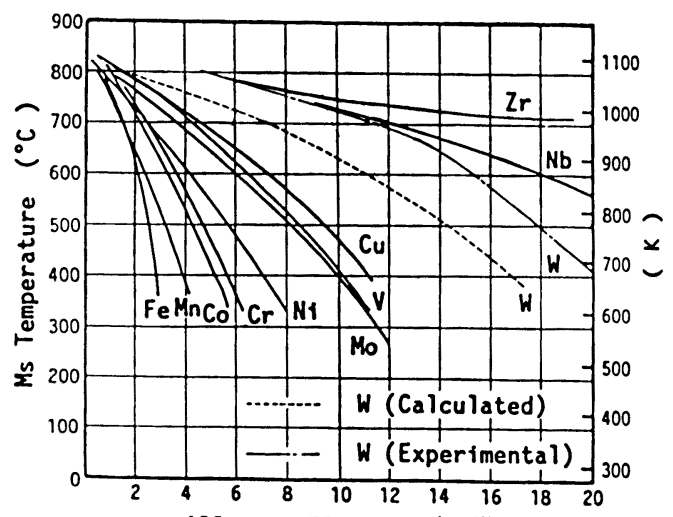

Alloying Element (wtz)

Fig. 12. Compositional dependence of the $M_{s}$ temperature of titanium alloys.

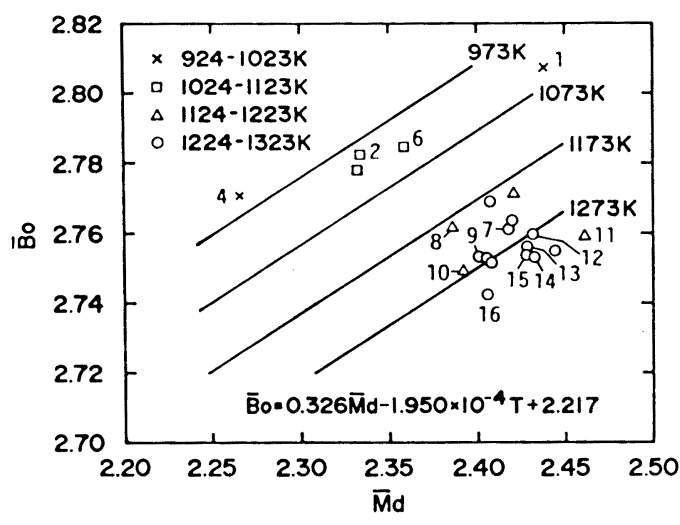

Ti Alloys

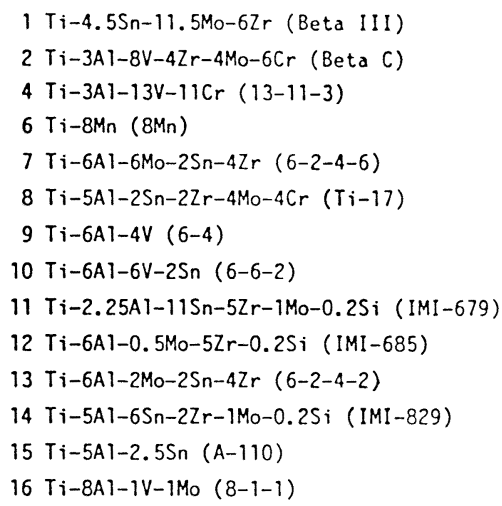

$1 \mathrm{Ti}-4.5 \mathrm{Sn}-11.5 \mathrm{Mo}-6 \mathrm{Zr}$ (Beta III)

$2 \mathrm{Ti}-3 \mathrm{AI}-8 \mathrm{~V}-4 \mathrm{Zr}-4 \mathrm{Mo}-6 \mathrm{Cr}$ (Beta C)

i-3A1-13V-11Cr $(13-11-3)$

$7 \mathrm{Ti}-6 \mathrm{Al}-6 \mathrm{Mo}-2 \mathrm{Sn}-4 \mathrm{Zr}(6-2-4-6)$

$8 \mathrm{Ti}-5 \mathrm{~A}]-2 \mathrm{Sn}-2 \mathrm{Zr}-4 \mathrm{Mo}-4 \mathrm{Cr}(\mathrm{Ti}-17)$

$T i-6 A 1-4 V(6-4)$

Ti-6Al-6V-2Sn $(6-6-2)$

12 Ti-6Al-0.5Mo-5Zr-0.2Si (IMI-685)

$13 \mathrm{Ti}-6 \mathrm{Al}-2 \mathrm{Mo}-2 \mathrm{Sn}-4 \mathrm{Zr}(6-2-4-2)$

$15 \mathrm{Ti}-5 \mathrm{~A} \mathrm{~T}-2.5 \mathrm{Sn}(\mathrm{A}-110)$

16 Ti-8AT-1V-1Mo (8-1-1)

Fig. 11. Four lines of showing the $\beta$ transus from $973 \mathrm{~K}$ to $1273 \mathrm{~K}$, and plots of the $\beta$ transus of commercial alloys.

プロットされている28). 例えば, No. 9 の Ti-6Al-4V の $\beta$ トランザスは約 $1260 \mathrm{~K}$ であり，○印（1 224〜 $1323 \mathrm{~K}$ の範囲) で示されている。 $\beta$ トランザス (TK) と $\bar{B}_{0}, \bar{M}_{d}$ の間には,

$$
\bar{B}_{0}=0.326 \bar{M}_{d}-1.95 \times 10^{-4} T+2.217
$$

の近似式が成立する．IMI-679（No. 11）を除き， $\beta$ トランザスの実測值と計算值との一致は良い。最近, 堀 谷らは29)，純チタンに $0.4 \mathrm{wt} \% \mathrm{Fe}$ を添加すると， $\beta$ 卜 ランザスが $10 \mathrm{~K}$ 下がるといら実験結果を報告している. 式(4)による計算では，それは約 $6 \mathrm{~K}$ 下がると見積も られ，両者の一致は比較的良い。このように式 (4)を使 えば，合金組成から $\beta$ トランザスを容易に予測できる.

\section{4 マルテンサイト变態開始温度 $\left(\boldsymbol{M}_{s}\right)$ の予測}

チタン合金を $\beta$ 相域から焼入れるとマルテンサイト
変態を起こし， $\alpha^{\prime}$ まなは $\alpha^{\prime \prime}$ マルテンサイトが現れ $ð^{30)} \cdot M_{s}$ 点の組成依存性も, 高温の $\beta$ 相の相安定性 を示すパラメーター $B_{0}$ と $M_{d}$ とより整理できる.

Fig. 12 は, 佐藤ら ${ }^{31}$ が求めた Ti-M 2 元合金の $M_{s}$ 点の組成変化である. このデータからマルテンサイ 卜变態の $B_{0}-M_{d}$ 線図が Fig. 13 の上万に, 各 $M_{s}$ 温 度で求まる。例えば Fig. 12 において， $M_{s}$ が $673 \mathrm{~K}$ $\left(400^{\circ} \mathrm{C}\right)$ の水平な直線と域る $\mathrm{Ti}-M 2$ 元系の $M_{s}$ 曲線の 交点の各組成を読み, $B_{0}, M_{d}$ を算出する，このことを $M$ に対して行い, Fig. 13 にプロットする. 他の $M_{s}$ 温 度でもこれを繰り返す。（ただし室温のデータは, 文献 32）による.）プロットされた点は，ある $M_{s}$ 点に注目 すれば， $\bar{B}_{0}-\bar{M}_{d}$ 線図の中で多少ばらついてはいるが， 一つの直線に沿つて分布している， $M_{s}$ 点が高くなる汪 


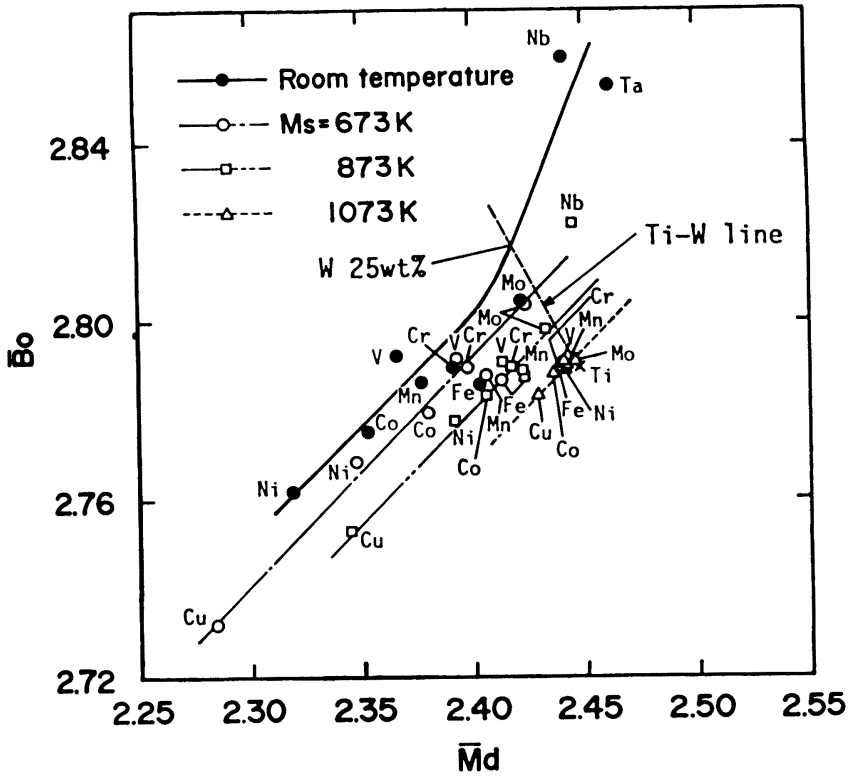

Fig. 13. Iso $M_{s}$-temperature lines drawn in the $\bar{B}_{0}-\bar{M}_{d}$ map.

ぞその直線は，図中で右下の方向へ移動している.

Wのデータは佐藤らの報告にはないが， その $M_{s}$ 組 成曲線も推定できる. Fig. 13 において, Ti-W 直線(点 線で示す）と，各 $M_{s}$ 温度で引かれた直線の交点の $B$ 。 (または $M_{d}$ ) の值から組成を算出し, Fig. 12 にプロ ットした結果が W(Calculated) である. DuwEz の実 験結果 ${ }^{33)} の \mathrm{~W}$ (Experimental) と比較すれば, 若干の相 違はあるものの，良くWの傾向を表している.

\section{4. 考察}

合金の状態を記述するパラメーターとして, HumEROTHERY ら ${ }^{34)}$ や DARKEN, GURRY ${ }^{35)}$ らにより, 電気 陰性度や金属半径が導入され，金属学の種々の問題（例 えば，合金固溶体の固溶限や結晶の構造安定性に関する 問題) に適用されてきた. しかし，これらパラメーター はいずれも純金属の值であるため, 命金効果を必ずしも 反映していない，一方， $M_{d}$ や $B_{0}$ は，現实の合金の状 態に近いクラスター模型を使つて，第 1 原理からの計算 で求められている. 従つて当然のことながら合金効果も それらパラメーターに反映されている。例えば， Ni 合 金で求めた $M_{d}$ パラメーターを使つて，オーステナイ 卜系合金固溶体の固溶限を定量的に見積もることができ $3^{36) ~ 38)}$. チタン合金においても，個々の合金元素の個 性が $M_{d}$ と $B_{0}$ の中に反映しているため,これらパラ メーターにより合金の相安定性が評価できたと考えられ る. チタン合金同様, bcc の $\mathrm{Fe}$ 合金の相安定性も $M_{d}$ と $B_{0}$ により議論できる ${ }^{16)}$.

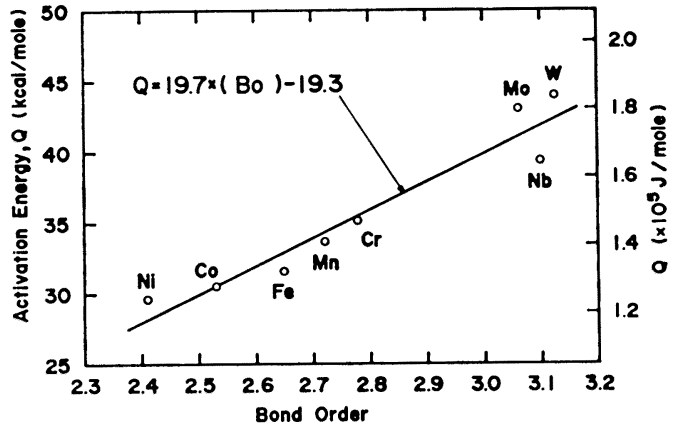

Fig. 14. Change of the activation energy for impurity diffusion in bcc $\mathrm{Ti}$ with the bond order, $B_{0}$.

相安定性のみならず，他の性質もこれらパラメーター によつて理解できる. 例党ば, Fig. 14 に, $\beta$-Ti 中の 不純物元素の拡散のための活性化エネルギー39)を, 結合 次数 $B_{0}$ で整理した結果を示寸，純金属において，その 自己拡散の活性化エネルギーは，その金属の溶融温度と 比例することが知られている3 ${ }^{39)}$. 従つて, 原子間の凝集 力と関係のあるパラメーターである結合次数と, 払散の 活性化エネルギーを結びつけることができるかもしれな い. 実際, Fig. 14 に示すように, 要移金属不純物の拡 散の活性化エネルギーQは, 結合次数に比例して単調に 変化している. 結合次数 $\left(B_{0}\right)$ とQとの間には次の関係 がある・

$$
Q=19.7 \cdot B_{0}-19.3
$$


この式に $\mathrm{Ti}$ の $B_{0}$ 值の 2.79 を入れて計算すると， $Q$ は $35.7 \mathrm{kcal} / \mathrm{mol}\left(=1.49 \times 10^{5} \mathrm{~J} / \mathrm{mol}\right)$ となる.この值 は $\mathrm{Ti}$ で報告されている $36.5 \mathrm{kcal} / \mathrm{mol}\left(=1.53 \times 10^{5} \mathrm{~J} /\right.$ mol) K近( 40 ).

\section{5. 結}

bcc Ti および hcp Ti の電子構造に及ぼす合金元素 の影響を，DV-X $\alpha$ クラスター法を用いて系統的に調べ た. 各種金属元素の合金効果を表す二つのパラメーター を求めた。それれは，合金元素の $d$ 軌道に関係したエ ネルギーレベル $\left(M_{d}\right)$ と原子間の結合次数 $\left(B_{0}\right)$ であ る.これら $M_{d}$ と $B_{0}$ を用いて, チタン合金の相安定 性を評価できる。すなわち， $\beta$ トランザスやマルテンサ イト変態開始温度 $\left(\boldsymbol{M}_{s}\right)$ の子測や, 実用合金の分類が可 能である.このほか， $\beta$ - Ti 中の不純物元素の拡散の活 性化ェネルギーも推定できることが分かつた． $B_{0}$ と $M_{d}$ はチタン合金を設計するとき有用なパラメーターである と思われる。

チタン合金のデータの整理に協力していただいた豊橋 技術科学大学，大学院の真屋岳良氏に謝意を表します。 本研究は, 財団法人, 東レ科学振興会上り研究助成を受 けて行われた，同財団に対し感謝致します，また電子構 造の計算は, 岡崎国立共同研究機構, 分子科学研究所電 子計算機センターの HITAC M-200Hを使つて行つ た、同計算機センターに対し厚くお礼を申し上げます。

\section{交献}

1) L. F. Matrheiss: Phys. Rev., 134 (1964), p. A970

2 ) S. L. Altmann and $C . J$. Bradley: Proc. Phys. Soc., 92 (1967), p. 764

3) E. H. Hygh and $R$. M. Welch: Phys. Rev. B, 1 (1970), p. 2424

4) R. M. Welch and E. H. Hygh: Phys. Rev. B, 4 (1971), p. 4261

5 ) O. Jepsen: Phys, Rev. B, 12 (1975), p. 2988

6 ) T. Asada and $K$. Terakura: J. Phys. F, 12 (1982), p. 1387

$7)$ G. $N$. Kамm and $J . R$. Anderson: Low Temperature Physics, Vol. 4 (1974) [Plenum]

8 ) D. E. Eastman: Electron Spectroscopy, ed. by D. A. Shirley (1972), p. 487 [North-Holland]

9 ) L. Ley, $O . B$. Dabbousi, $S . P$. Kowalczyk, $F$. $R$. McFeely and $D$. A. Shirley: Phys. Rev. B, 16 (1977), p. 5372

10) $H$. Höchst, $P$. Steiner, $G$. Reiter and $S$. HüfNER: Z. Phys. B, 42 (1981), p. 199

11) F. Riehle, $T h$. Wolf and $G$. Politis: Z. Phys. B, 47 (1982), p. 201

12) J. C. Slater: Quantum Theory of Molecules and Solids, Vol. 4 (1974) [McGraw-Hill]

13) $H$. Adachi, $M$. Tsukada and $C$. Satoko: J.
Phys. Soc. Japan, 45 (1978), p. 875

14) M. Morinaga, $N$. Yukawa and $H$. Adachi: J. Phys. Soc. Japan, 53 (1984), p. 653

15）村上隊太蚛，化非：沙：非鉄金属材料学(1978), p. 107 [胡食胃坫]

16) $M$. Morinaga, $N$. Yukawa and $H$. Adachi: J. Phys. F, 15 (1985), p. 1071

17) E. C. Snow and J.T. Waber: Acta Metall., $17(1969)$, p. 623

18) D. G. Pettifor: J. Phys. C, 3 (1970), p. 367

19) R. E. Watson and L. H. Bennett: Phys. Rev. B, 18 (1978), p. 6439

20) E. T. Teatum, $K . A$. Gschneidner, Jr. and $J$. T. Waber: Report of Los Alamos Scientific Laboratory, LA-2345 (1968) [U.S. Department of Commerce]

21) D. Hackenbracht and $J$. Kübler: J. Phys. F, 10 (1980), p. 427

22) M. Morinaga, $N$. Yukawa, $H$. Adachi and $H$. Ezaki: Superalloys 1984, ed. by $M$. Gell et al. (1984), p. 523 [The Metallurgical Society of AIME]

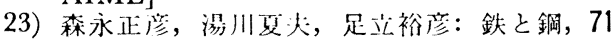
(1985), p. 1441

24) W. G. Moffatt: The Handbook of Binary Phase Diagrams, Vol. 2 (1972) [General Electric Company]

25) R. A. Wood and $R . J$. Farror: Titanium Alloys Handbook (1972) [Metals and Ceramics Information Cienter]

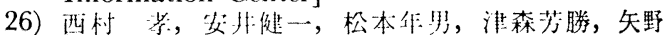
博俊：鉄と鋼，71（1985), S 753

27) E. K. Molchanova: Phase Diagrams of Titanium Alloys (1965) [Israel Program for Scientific Translation]

28) $H$. HuCEK and $M$. WAHL: Handbook of International Alloy Compositions \& Designations, Vol. 1 (1976) [Metals and Ceramics Information Cetner]

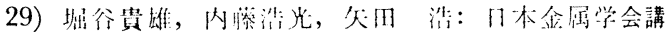
激概装 $(1985.4$ H) , p. 353

30) C. Hammond and P. M. Kelly: The Science, Technology and Application of Titanium, ed. by $R$. I. Jaffee and N. E. Promisel (1970), p. 659 [Pergamon Press]

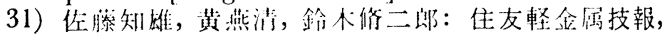
3 (1962), p. 314

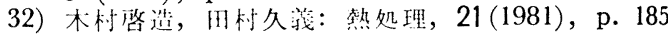

33) P. Duwez: Trans. ASM, 45 (1953), p. 934

34) $W$. Hume-Rothery and $G . V$. Raynor: Structure of Metals and Alloys (1954) [The Institute of Metals]

35) L. Darken and $R$. W. Gurry: Physical Chemistry of Metals (1953) [McGraw-Hill]

36) $M$. Morinaga, $N$. Yukawa, $H$. Ezaki and $H$. ADACHI: Phil. Mag. A, 51 (1985), p. 233 and p. 247

37）森永正彦，晹川夏夫，足立裕彦：日本金属学会会 報, 23 (1984), p. 911

38）晹川夏夫：新材料阙発と材料設訣学，三息良皘， 岩田修一緗 (1985)，p. 79 [ソフトサイエンス社]

39) J. Askill: Tracer Diffusion Data for Metals, Alloys and Simple Oxides (1970) [Plenum]

40) E. Walsö de Reca and C. Pampillio: Acta Metall., 15 (1967), p. 1263 